\title{
Assessing the Access to Finance by Small and Medium-Sized Enterprises from Financial Institutions in Blantyre City-Malawi
}

\author{
Nelson Nanteleza Ndala ${ }^{1}$ \\ ${ }^{1}$ School of Commerce-Malawi College of Accountancy, Malawi \\ Correspondence: Nelson Nanteleza Ndala, School of Commerce-Malawi College of Accountancy, Malawi. \\ E-mail: nelsonndala@yahoo.com/nanteleza70@gmail.com
}

Received: February 13, 2019

Accepted: March 20, 2019

Online Published: April 18, 2019

doi:10.5539/ijbm.v14n5p84

URL: https://doi.org/10.5539/ijbm.v14n5p84

\begin{abstract}
SMEs are an integral part of the economy in Malawi. The paper assesses the access to finance by SMEs from financial institutions in Malawi by highlighting the obstacles that SMEs face in their effort to raise finance. The quantitative research approach was adopted in conducting the study. Questionnaires were circulated to 100 SMEs in the City of Blantyre-Ginnery Corner and the SMEs were selected using the random sampling techniques. The following major findings were revealed. There are financial institutions that are willing to provide funds to SMEs for growth and expansion but most Malawian SMEs fail to meet the lending requirements demanded by these institutions. Chief amongst these is the inability by most SMEs to provide collateral or security and audited financial statements for their businesses. On the other hand, for the small number that is able to access finance, they are faced with high interest rates which make it very difficult for them to grow. The other constraints include lack of finance, stiff competition in the sector, high taxes and corruption and bribes to access contracts. Another interesting revelation is that SMEs relationship with their bankers is not healthy. Most SMEs consider their relationship to be average despite recent focus by the banks on SMEs businesses. The study recommends the enforcement of the Credit Reference Bureau Act 2010 to help financial institutions identify and lend to creditworthy SMEs; banks should soften their adverse risk attitude of over reliance on collateral rather than on business cash flows. The government should also consider provision of tax incentives to banks' lending to SMEs; stabilisation of the economy to achieve lower inflation and interest rates and formulation of government policy on SMEs that would compel Ministries, Departments and Agencies to allocate a proportion of contracts to SMEs in any tender. Lastly, financial institutions should revisit their approach to SME banking.
\end{abstract}

Keywords: small and medium enterprises, finance, banks

\section{Introduction}

Evidence about the critical role played by the small and medium enterprises (SMEs) and the contribution they make to the socio-economic development of economies has been well documented. Peterholf, Romeo \& Calvey (2014) reported that small and medium enterprises account for 90 percent of all businesses globally. In addition, SMEs generate 60 percent of employment worldwide and provide jobs to roughly 80 percent of the workforce in the developed world. Another important finding was that 50 percent of global Gross Value Added (GVA) is contributed by SMEs. In Malawi, the findings by the comprehensive 2012 FinScope SME survey that 1,050,320people were employed by just around 41 percent of the country's SMEs also attest to the pivotal role of SMEs in the Malawian economy. The contribution of small and medium scale businesses to socio-economic growth and development of nations takes many forms including boosting public revenue collections through various forms of taxation, provision of goods and services to the general public and, more importantly, poverty alleviation through creation of employment and economic empowerment of citizens. Sadly, financing has been identified as one single factor that challenges the survival and growth of SMEs, not only in Malawi, but in the developed and developing world. The FinScope (2012) study revealed that 59 percent of SMEs were excluded from financial services, as opposed to 31 percent that are formally served by some sort of financial system, with the balance relying on informal services. Only 22 percent are banked. Over three quarters do not borrow funds, primarily because they doubt their ability to repay loans. Of those who borrow, informal credit systems tend to be the primary source of credit. Kazooba (2006) and World Bank(2009) reveal that poor transportation, inadequately educated workforce, unreliable power supply are among a host of factors inhibiting the growth and 
survival of SMEs, access to finance lead the list, at least according to the available evidence. The World Bank Enterprise Survey (2009) reveal that out of the many obstacles to their business growth which include poor transportation, unreliable power supply, exorbitant tax rates, inadequately educated workforce, crime, complicated business licensing procedures, corruption and limited access to land, 45.6 percent of SMEs recounted limited access to finance as the main obstacle. This evidently shows how counterproductive financing challenges have become in defining the survival and growth of most SMEs in Malawi. Access to finance gives SMEs the chance to develop their businesses and to acquire better technologies for production, therefore, ensuring their competiveness. Despite this acknowledgement, there still exists a huge challenge for SMEs in Malawi pertaining to access to initial and expansion capital funds from traditional commercial banks. This is also shown by the fact that the majority of commercial bank loans offered to SMEs are often limited to a period far too short to pay off any sizeable investment. In addition, banks prefer to lend to the Government rather than private sector borrowers because the risk involved is lesser and higher returns are offered. It is such apathy for the SMEs that has crowded out most private sector borrowers and increased the cost of capital for them. Most SMEs are owner managed and funded. They operate as one man business or family owned businesses. They are usually informal and very few have formal structures. Moore et al (2008) define a family owned business as a company where two or more members of the same family own or operate together or in succession. Moore et al (2008) further contend that these businesses grow if there is commitment of family members and the founder's imprint on the family business culture.

Finance for running SMEs come from a variety of sources. Nuttal (2002) argues that finance can be obtained from both internal sources and external sources. Internal sources of finance include retention of profits and reserves, selling assets and shareholders' capital injection. External sources include family and friends especially for small businesses, banks, hire purchase, trade credit, factoring, leasing, debentures and corporate bonds, venture capital and issuing shares to the public. Nuttal (2002) further argues that internal sources of finance are not so popular compared to external sources of finance. Stokes et al (2010) identify the following as some of the sources of finance for SMEs: asset finance, international trade finance, leasing, hire purchase, factoring or invoice discounting, trade credit and loans. Moore et al (2008) cites sources of finance which include personal savings, friends and family commercial banks, business suppliers, asset based lenders, venture capital firms, commercial based financial institutions, large corporations and public sale of stock. Brealey et al (2012) argues that SMEs can also obtain finance from venture capital and Initial Public Offering. Infant SMEs can raise venture capital to carry them through the point where they can make the first public issue of stock. SMEs can use the alternative stock market that is designed for small companies as the entry requirements are not restrictive. The alternative stock market is open at the Malawi Stock Exchange but no SMEs have taken up the offer at the moment.

According to the Reserve Bank of Malawi, Financial Supervision Annual Report (2015) banks are the most important source of external finance for the SME sector especially business loans and overdrafts. The most common sources of capital for SMEs in Malawi include owners capital largely obtained out of savings, retrenchment payouts, selling of assets, family and friends, micro finance institutions and informal investors. Bank loans and overdrafts are sparingly used as most SMEs cannot access them.

\subsection{Problem Statement}

MSME Main Report (2012) revealed that in Malawi the majority of SMEs are operated as sole proprietorships and very rarely as partnerships. There are some private limited companies that are SMEs as well. One primary responsibility of business owners is to contribute capital for the set up and running of the business. As the businesses grow, there is need for additional capital injection to satisfy strategic growth objectives. As the business further grows bigger, it becomes virtually impossible for the owners to finance the business singlehandedly. It is at this stage that the owner seeks other ways of obtaining capital for the business operations. Due to this growth, there could be a probable necessity for any business to borrow at some stage of their lifespan and banks come in handy as financing institutions. SMEs can only grow if there is access to finance and other forms of finance cannot sufficiently support them.

World Bank (2009) study shows that most of the big companies today started their operations on a very small scale. Some started as SMEs and have grown exponentially over the years into large companies. SMEs are usually sole traders and partnerships and small private companies whose owners contribute funds for the setting up and working capital needs of the business. This funding from owners, family and friends, lifetime savings, sale of assets, among others may not be enough forever, as such SMEs also require finance from commercial banks at some point in their economic lives, hence, the need for looking at obstacles being faced in accessing financing from the banks. Despite the significant role of SMEs in an economy, the financial constraints they face 
in their businesses are too much and this has a corresponding negative impact on their development and the economy in general. Lack of management skills, inadequate capital base to meet collateral requirements by financial institutions before credit is given out, lack of support for large businesses, absence of conducive business climate have been cited by researchers as major obstacles blocking SMEs in accessing credit from financial institutions (Coleman, 2000).

The overall objective of this paper is to establish obstacles that SMEs face when accessing finance from listed commercial banks in Blantyre City, Malawi. The specific objectives of the paper are:

a) To identify obstacles that SMEs face in accessing finance from financial institutions in Blantyre City, Malawi.

b) To assess the challenges faced by financial institutions to provide finance to SME's in Blantyre City, Malawi.

c) To determine how effective financial institutions communicate their lending requirements to SME's and alternative sources to finance SME's in Blantyre City, Malawi.

\section{Literature Review}

The definition of SME is based on five main parameters; labour, capital, loan size, fixed asset and annual sales turnover. Organizations often use one criterion to define SMEs. The size limit is one of the most common definitions in developing countries. SME Policy draft (2015) provides the definition of SMEs in Malawi which are categorized based on the number of employees, annual turnover and maximum assets. The table below summarizes the categories and the definitions:

Table 1. Official definitions of SME's in Malawi

\begin{tabular}{|l|l|l|l|}
$\begin{array}{l}\text { Enterprise } \\
\text { Size }\end{array}$ & $\begin{array}{l}\text { Employment } \\
\text { No. of employees }\end{array}$ & $\begin{array}{l}\text { Annual turnover (in Malawi } \\
\text { Kwacha) }\end{array}$ & $\begin{array}{l}\text { Maximum assets (exclude } \\
\text { land and building - for } \\
\text { manufacturing } \\
\text { enterprises) }\end{array}$ \\
\hline Micro & $1-4$ & Up to K5,000,000.00 & K1,000,000.00 \\
\hline Small & $5-20$ & K5,000,001-K50,000,000.00 & K20,000,000.00 \\
\hline Medium & $21-99$ & K50,000,001- K500,000,000.00 & K250,000,000.00 \\
\hline
\end{tabular}

Like other businesses, SMEs can take several forms. Scarborough (2013) argues that the most popular form of ownership remains the sole proprietorship since it is simple to create, least costly to begin, guarantees total decision making authority to the owner; there are no special legal restrictions and it is very easy to discontinue operations. Further, Scarborough (2013) gives other forms of SMEs like partnerships, which can take the form of limited partnerships, limited liability partnerships; corporations and joint ventures. According to Kambewa, Patrick and Tekere (2007), data on the SME sector in Malawi is scattered and outdated making it very difficult to find information on which to base policy decisions by the Government and other stakeholders. SMEs in Malawi are comprised of several attributes and these include: SMEs have very low purchasing power particularly in the rural areas; they are usually one man businesses or family owned businesses, they face stiff competition from large companies; they lack management skills; they lack a clear succession plans which generally kills business upon the death of the SME owner; they lack capacity to supply large orders; they lack support from financial institutions for working capital and expansion projects due to lack of collateral; SMEs face stiff competition for access to raw materials; SMEs have difficulties in accessing finance from banks and other financial institutions as well as lack proper support from Government and SME sector is characterized by low levels of education and training.

SMEs in Malawi have few employees who are mostly children, relatives and friends of the owner, hence, lack separation of ownership and control, the lack of ownership and control poses serious challenges in the management of funds. SMEs play a very significant role in the economy. Kambewa et al. (2007) found that SMEs contribute about 13 per cent to the export sector in Malawi. Scarborough (2013) cites the following factors for the growth of SMEs: entrepreneurial education, shift to a service economy from a manufacturing one, technology advancements, the need for independent lifestyle, demographic and economic factors, the development of e-commerce and the World Wide Web. There are no laws that compel commercial banks to set up SMEs business units in most African countries including Malawi that are specifically dedicated to serving the needs of entrepreneurs in the private sector. Grover \& Suominen (2014) investigated 10,000 SMEs access to finance in 80 
different countries and found that the key factors driving SMEs success and sustainable growth were easy access to finance.

\subsection{Choice of Financing Theories}

While the overarching decision is between debt and equity, these financing sources are not necessarily appropriate for or accessible to all of the different types of SMEs. The nature of funding required by and accessible to an enterprise depends on its financial growth life-cycle stage (Mullen, 2012). The funding choices made by the entrepreneurs are generally explained by two specific theories which are:

- Pecking Order Theory suggests that it is the owner-managers or individual entrepreneur decision as to which finance sources to approach at any given point in time. The theory shows that there is a pecking order. The preferred sources of finance, whereby entrepreneurs tend to prefer own internal sources of finance over external debt, which in turn is preferred over external finance and external equity is the least preferred source of all. It also argues that the cost of financing increases with asymmetric data as they opt for internal financing then debt and lastly equity is used as last resort (Puntaler, 2010). The premise of this theory is that there is no well-defined, optimal capital structure, as it is up to the owner-manager to decide which financing sources to approach at any given time. Myers (1984) posits that entrepreneurs tend to prefer own, internal sources of finance over debt, which in turn takes precedence over external mezzanine finance and external equity as the last-ranked source of financing preferred by entrepreneurs. Consequently, this hierarchical financing over time determines the debt ratio (Briozzo \& Vigier, 2009; Fatoki \& Smith, 2012).

- Trade-off Theory derives from Modigliani-Miller capital structure irrelevancy theory and particularly from the tax-added model which implies that an optimal capital structure for a firm is achieved by being completely financed with debt if bankruptcy costs are excluded. It takes into account the benefits and disadvantages of financing a business through debt rather than equity. This theory explains that firms are often financed partly with equity and debt and it acknowledges that taking on more debt increases the tax shield effect of the interest payable, which reduces a ventures tax burden. But taking on more debt increases the risk of over gearing, financial distress and bankruptcy, which involves a variety of costs to the business. The theory, therefore, proposes that SME's choose finance sources based on a trade-off between increased tax shield and increased bankruptcy costs (Agarwal, 2013). The trade-off theory posits that SME's opt for financing sources on the basis of a trade-off between increased tax savings and increased bankruptcy costs. The theory acknowledges that interest payments are tax deductible thus minimizing the cost of capital and maximising equity holders' wealth through the use of debt. On the contrary, there is a real risk of over-gearing, financial distress and consequently bankruptcy (Fatoki \& Smith, 2012).

\subsection{Available Banks in Malawi}

According to Hameed (2012), a bank is an establishment which deals in money, receiving it on deposit from customers, hounouring customer's drawings against such deposits on demand, collecting cheques for customers and lending or investing surplus deposits until they are required for repayment. The banker is an institution or individual who is always ready to receive money on deposits to be returned against the cheques of their depositors (Hameed, 2012). According to the Malawi Banking Industry Report - Reserve Bank of Malawi (2015) there are ten licensed commercial banks in Malawi which provide a wide range of commercial banking services including acceptance of deposits in the form of demand, savings and time; foreign exchange services, provision of short and medium term credit facilities and financing of international trade. Out of the nine banks above, only four banks are listed on the Malawi Stock Exchange (MSE) namely Standard Bank Limited, National Bank of Malawi, NBS Bank Limited and First Merchant Bank Limited. Standard Bank Limited was the first bank to be listed on the MSE in 1998.There is one leasing company, the Leasing and Finance Company of Malawi (LFC) that provides asset financing services to companies and households wishing to purchase motor vehicles, machinery or other capital goods. The industry has a single discount house, First Discount House Limited. Its principal business is providing liquidity to the secondary market for government bills and registered stocks by accepting to purchase or sell these financial instruments from or to the general public (Malawi Banking Industry Report - Reserve Bank of Malawi, 2015).

\subsection{Constraints Faced by SMEs in Accessing Finance}

SMEs are the future of any economy hence there is a lot of interest in their development by governments, international organisations and the community. SMEs require finance for working capital and business expansion operations. Various commentators across the world have debated some of the constraints that SMEs face in accessing finance to develop their operations. There is a significant shortage of investment capital for SMEs in developing countries including Malawi. In Africa, SME growth is constrained by lack of business acumen, 
collateral and established track records in the formal economy. Scarborough (2013) contends that SMEs face the disadvantage of uncertainty of income as there is no guarantee that the SME will earn enough money to survive. Scarborough (2013) further argues that SMEs owners carry the risk of losing their entire investment; the need to endure long hours and hard work; the likelihood to experience a lower quality of life until the business gets established. In addition, Scarborough (2013) states that SME owners face high levels of stress as failure of business might mean total ruin and anxiety. They also face discouragement and disillusionment in their businesses.

\subsection{Constraints for SME Growth}

Kalaile (2016) argues that everyone can start up an SME venture but very few SMEs manage to grow. Two major sets of impediments to the success of SMEs are outlined:

a. The first one is environmental and the other set is the internal and personal constraints of the entrepreneurs that stem from an education system that does not nurture entrepreneurship from the formative years. Malawi has a tough macroeconomic environment that is characterised by high inflation rates according to data released by National Statistics Office, high interest rates, shallowness of the market where there is a very small middle class with disposable income and very weak industrial and corporate sector and very heavy dependence on a single client, the government.

b. Kalaile (2016) further argues that most entrepreneurs fail to grow their business due to management inability to acquire knowledge of financial management, computer literacy and understanding of the legal system, tax system, human resource management and any number of technical systems related to the industry that the business is in. Growth challenges for SMES still exist. Small and Medium Enterprises Association of Malawi (SMEA) argues that SMEs still face challenges like access to finance, high borrowing costs and the requirements by lenders to ask for provision of collateral. Mobile collateral like cars are not accepted as well by most lenders. Furthermore, banks are reluctant to use SMEA as guarantor for finance advanced to SMEs. It is further argued that banks do not divulge reasons for refusing granting loans to SMEs for professional reasons and this does not help the SMEs as it is not possible for applicants to know where they need to improve. SMEA further claims that banks do not partner with SMEs associations, do not fully understand the operations of the SMEs, favour to provide short term finance and give very little attention to SMEs as they are assured of big businesses from big players like the government, international organisations and large firms. Evidence has shown that when SMEs become internationalized, particularly when they start exporting to foreign markets, their contribution to their home economy increases. For this to happen, substantial barriers need to be overcome. SMEs can face difficulties in financing international activity, identifying opportunities and making appropriate contacts in their target markets (Wymenga, Spanikova, Barker, Konings \& Canton, 2012).

\subsection{Sources of Financing for SMEs}

A number of sources of finance exist but many of them may not be accessible to companies of small and medium sizes. The various means by which small and medium enterprises can have access to finance for either start-up or for operational purposes are as follows:

- Personal Savings and Borrowing from Family \& Friends: This is the most common source of finance to the small businesses in Malawi. They come in a form of personal contributions like village banking, which refers to a traditional group contribution scheme where individuals come together and agree on an amount of money to be contributed on regular intervals and given to one member at a time which will continue until the last person takes his/her contribution and another form of cash balances that can be accumulated by the entrepreneur. It can also come from friends and family in a form of an informal loan without interest. This source of finance is the cheapest and comes at no cost to an entrepreneur (Frimpong \& Antwi, 2014)

- Private Equity: Private equity firms make capital investments in established firms with high growth potential. The investments are medium to long-term in nature and come with the active participation of the investor with respect to introducing operational improvements over the investment period. A private equity exits by investment through the sale of stake to other private equity firms or trade buyers, and Initial Public Offerings (Mullen, 2012).

- Share Capital and Retained Earnings: Share capital is the amount of money an investor or entrepreneur is willing to invest as a seed capital to start a business while retain earnings is the amount of profit that is made from business operations and kept for potential re-investment into the business or to cover poor cash-flow (Frimpong \& Antwi, 2014). The entrepreneur can also raise this finance by selling some of the rights to other interested parties. The buyers of this right are now part owners of the business and have the power to make 
decisions in the interest of the business. This source of finance is also cheap but not more than the personal savings. The shareholders are entitled to the yearly dividend but this entitlement cannot be enforced if the business had a bad season.

- Bank Loans \& Overdraft: This is common source of finance to the small businesses (Coffie, 2012). Bank loans are sometimes too expensive for start-ups since they come with fixed interests and repayment of principal over a particular period of time. In spite of the high interests charged by the banks for the loan, they also request for collaterals in the form of fixed assets that can be liquidated in case of default in payment. Overdraft is money withdrawn in excess of savings and can be paid back with interest within a particular period. Overdrafts are usually for shorter periods than a loan but they are more expensive than bank loans. Overdrafts are more flexible and help businesses meet immediate cash needs when there is not enough time for loans to be processed.

- Business Angels: Business angels are individual professionals who invest money in start-up companies. Business angels typically prefer to invest in young companies that have good prospects. They usually invest capital into the start-up companies in exchange for ownership right or in a form of convertible bonds. Convertible bonds are bonds with an option to turn or convert them at a later period into equity at an agreed price (Quaye \& Sarbah, 2014).

- Venture Capital: This is an amount of money invested or is made available to be invested into a start-up company. Venture capitalists usually invest in businesses with high risks and high returns and do it in exchange of owner equity. Though the definition states that they are invested into start-ups, this is usually not the case. Venture capitalists invest large sums of money and hence the small start-up businesses are too small for them which forces them to invest in medium firms which are already established (Quaye \& Sarbah, 2014).

- Mezzanine Finance: Mezzanine finance is a form of a quasi-equity financing instrument that is a hybrid of equity and debt. With quasi-equity, the remuneration of the investor is largely or entirely dependent on revenue and or profit performance of the enterprise. This form of finance is often used to finance expansion of existing enterprises. Mezzanine finance can be in the form of preference shares, convertible bonds, shareholder loans and unincorporated joint ventures. Naturally, these types of instruments require a high degree of informational symmetry between investor and SMEs owners (Mullen, 2012).

\subsection{Lending Requirements SMEs must Satisfy to Access Finance from Various Banks}

The main business of banks is to act as financial intermediary. They do this by accepting deposits from those customers, including SMEs that have excess cash and lend a portion of the deposits accepted to those customers who have deficits. Although banks need to accept some amount of credit risk (if not, they would not be able to do business), they will have a credit approval process to ensure that excessive amounts of credit exposure are not taken on. To do this, banks use credit granting criteria whereby only borrowers with risk profiles within acceptable limits set by the bank's board of directors and senior management will be extended credit. These criteria will identify and document: the purpose of the loan; how the borrower proposes to repay the loan; the borrower's character and business expertise; the borrower's credit worthiness including their credit history; terms and conditions of the loan including any covenants and adequacy and enforceability of collateral or guarantees. If the borrower is deemed to meet all the foregoing criteria, the bank will generally approve the loan. However, the bank will also monitor the borrower's financial performance over time to ensure that the creditworthiness of the borrower remains within acceptable limits. Some of the main lending requirements that SMEs must satisfy to commercial banks to acquire finance are listed below as obtained from the respective banks websites and marketing brochures.

Standard Bank Limited: Cash flow projections, business financial statements, bank statements, personal statements of members or directors, brief business profile, debtors aged list, brief management profile and acceptable assets for security or collateral (Standard Bank, 2015 \& SME Banking Brochures, 2015).

National Bank of Malawi: Application Letter or Completed application form, bank statements for 12 months if multi-banked, copy of lease or title deed, valuation Report not more than five years, copy of certificate of search, financial Statements as in projected cash flow statement, Income and Expenditure Statement, Balance Sheet and Management accounts where the financial statements are of more than six months old, asset and Liability Statement -if financials are not available, signed contracts, business profile, lien over deposit account, assignment of contract proceeds and statement of assets and liabilities (National Bank 2015 \& SME Banking Brochures, 2015).

NBS Bank Limited: Valid contract, assignment of contract proceeds, actively banking with NBS Bank for at least six months, irrevocable Letter of Undertaking to have the proceeds remitted to their NBS Bank account, 
cash flow projections, six months business experience and marketable collateral (SME Banking Brochures, 2015).

First Merchant Bank Limited: Valid contract and assignment of contract proceeds, actively banking with FMB for at least six months, cash flow projections, six months business experience and marketable collateral (First Merchant Bank, 2015 \& SME Banking Brochures, 2015).

\subsection{Criteria Used by Banks to Lend SMEs Finance}

NPL Guidance (2016) states that banks usually adopt the approaches below as a precaution in lending finance to SMEs. Firstly, going concern scenario in which banks look forward to future earnings as evidence of repayment ability of the business. This approach requires more analytical skills, more information and monitoring which may be costly to administer. Secondly, the going concern or liquidation scenario which takes a security based lending approach. The emphasis of this approach is on the past and current financial situation rather than future projections.

Olowe et al. (2013) found that financial services obtained from commercial banks have a positive significant impact on SMEs growth in country in that the duration of the loan has positive impact on SMEs growth. However, this is not statistically significant compared to high interest rate, collateral or security and frequency of loan repayment which can cripple the expansion of SMEs in a country.

In addition, Quainoo (2011) found that a significant number of the SMEs benefitted from the loans even though only few of them were capable enough to secure the required amount needed. Interestingly, the majority of the SMEs acknowledge positive contributions of loans towards increasing their returns and sales thus placing them in the competitive arena.

Akeem (2014) revealed that there is a positive correlation between loans granted by banks and the growth and development of the SMEs and found that the SMEs cannot be concentrated in an area if they are not effectively financed due to the relationship that exists between the banks and SMEs.

Mukamuganga (2011) found that small and medium enterprises accompanied by other approaches like infrastructure improvement can lead to rural development in a country. Nyandwi (2013) found that SMEs employ 22 percent of the adult population in developing countries. The United Nations Industrial Development Organization estimates that SMEs represent over 90 percent of private business and contribute to more than 50 percent of employment and of gross domestic product (GDP) in most African countries. Torre et al. (2010) also attribute hindrances of SME access to finance, making it difficult to ascertain if firms have the capacity to pay back by investing in viable projects, and the willingness to pay due to moral hazard. This particularly undermines credit access from institutions that engage in more impersonal financing that require hard, objective, and transparent information.

Nofsinger \& Wang (2011) suggest that information asymmetry and moral hazard problems complicate access to start-up capital. They find that entrepreneurial experience is helpful in obtaining financing from institutional investors and that the legal environment is important for access to external financing. The amount and diversity of sources of external financing are associated with high levels of property rights, contract enforcement, and corruption protection. Strict labor regulations can distort firm growth by raising the opportunity cost of firms to hire and fire workers. SMEs are more adversely affected by such policies because they do not have the capacity of large firms to adhere to these regulations.

Furthermore, Mayowa (2014) found that commercial banks credit to SMEs, saving and time deposit of commercial banks exert a positive influence on SMEs development proxy by wholesale and retail trade output as a component of GDP, while exchange rate and interest rate exhibit adversative effect on SMEs development.

\section{Method}

The survey questionnaires were targeted at SMEs within the City of Blantyre. The target sample included SMEs that borrowed from commercial banks and those that had never borrowed from commercial banks. The simple random sampling was employed so as to give every SME in the population an equal chance of being selected. The researcher first identified the SMEs that have bank accounts, registered businesses and borrow from any one of the listed banks in Malawi. The listed banks were chosen because they are public entities, therefore, it was relatively easy to get their lending information. A sample size of 100 SMEs within Blantyre City was chosen and the questionnaire was administered on the owners. Sveinung et al. (2010) argues that most SMEs operate in cities than in villages in most third world countries including Malawi, as such, a sample that effectively targets urban SMEs is considered representative enough of the population. 


\section{Research Findings}

Out of the 100 questionnaires circulated, 48 were completed and returned representing 48 percent response rate, which was deemed adequate considering the time given to the respondents and the fact that most SMEs are very skeptical in disclosing information about their businesses for fear of the unknown as most of them suspected that data was being collected for taxation purposes. Out of the 48 respondents, 27 representing 57 percent had their businesses registered as sole proprietors, 13 representing 26 percent were registered as family owned businesses respectively, 6 representing 13 percent were registered as partnerships and only 2 representing 4 percent were registered as private companies.

The 48 percent responses received centered on the general business services and agricultural sectors. General business services sector was the highest with 31 representing 65 percent of the total responses, followed by the agricultural sector that accounted for 5 representing 11 percent, then the 4 from retail and wholesale trading representing $8 \%$, then the transport sector at 4 representing 8 percent and it is only the food and hospitality sector that had no responses.

In terms of the annual turnover, for the 48 participating SMEs 21 of them recorded an annual turnover of over MK10 million representing 43 percent of the total respondents which is concentrated typically in the agricultural, general business services and transport sectors of the economy, 15 representing 31 percent of them had an annual turnover ranging between MK500, 000 and MK4 million, 8 representing 17 percent had an annual turnover ranging between MK4 million and MK10 million and only 4 participant SMEs representing 9 percent had an average annual turnover of less than MK500, 000 .

Furthermore, the study sought to establish the length of time the participating SMEs has been in business in the various sectors. In total 19 respondents accounting for 39 percent of total respondents have operated their businesses for a period ranging between 6 and 10 years, 15 respondents accounting for 30 percent of total respondents have operated their businesses for a period ranging between 1 and 5 years, 10 respondents accounting for 22 percent of total respondents have operated their businesses for a period ranging between 11 and 15 years, only 4 respondents accounted for 9 percent of the total respondents, have operated their businesses for less than 1 year and there were no SMEs that had been in business for over 15 years.

It was also revealed that 6 respondents representing 13 percent were holding JCE's, 12 representing 25 percentage were holding MSCE's, 12 representing 25 percent were holding bachelor's degree, others who were 18 represented 37 percent and none had master's degree representing zero percent.

\subsection{Challenges SMEs Face in Accessing Finance}

According to the survey lack of finance was 29 percent, competition was 21 percent, high taxes was 15 percent, corruption and bribes was 11 percent, government incentives was 5 percent, crime and theft was 5 percent, while others were 3 percent and high interest rates were 14 representing 11 percent. Lack of management skills, crime and theft as well as lack of government incentives were considered to be minor challenges to the growth of SMEs.

Table 2. Interest rate structure (percent)

\begin{tabular}{llllllllllllll}
\hline & 2013 & & \multicolumn{3}{c}{2014} & \multicolumn{4}{c}{2015} & & \multicolumn{3}{c}{2016} \\
& Q1 & Q2 & Q3 & Q4 & Q1 & Q2 & Q3 & Q4 & Q1 & Q2 & Q3 & Q4 & Q1 \\
\hline Policy rate & 25.00 & 25.00 & 25.00 & 25.00 & 25.00 & 25.00 & 22.50 & 25.00 & 25.00 & 25.00 & 22.50 & 27.00 & 27.00 \\
Base lending rate & 37.50 & 40.83 & 37.60 & 37.77 & 37.13 & 37.13 & 34.33 & 38.21 & 38.21 & 38.21 & 33.43 & 36.29 & 36.29 \\
Savings rate & 11.00 & 12.09 & 8.95 & 8.98 & 8.98 & 8.98 & 7.76 & 7.76 & 7.76 & 7.76 & 7.76 & 7.36 & 7.36 \\
\hline
\end{tabular}

As seen in Table 2 interest rates have been very high over the previous three years. Policy rate has been maintained at an average of around 25 percent since 2013 as a result banks base lending rates have averaged around 38 percent. The findings also showed that 77 percent of the total respondents were denied access to finance while only 23 percent were granted access to finance by banks. The results from the research showed various factors hindering SMEs in securing finance for the growth and expansion of their businesses. It was shown that out of 48,24 respondents representing 50 percent ranked inability to meet lending criteria as the major factor preventing them from accessing finance from banks, 18 representing 38 percent ranked lack of collateral or security to pledge as factors affecting their ability to access finance, 3 representing 6 percent stated that lack of financial information for the business was a major factor that prevented them from accessing finance while none representing believe that lack of experienced management team is a factor that prevented 
them from accessing finance.

A total of 28 respondents representing 57 percent said their failure to access finance was due to very high interest rates which makes it impossible to use bank loans in their businesses, 14 respondents representing 29 percent stated that lack of collateral or security to pledge as the main reasons banks refused to grant them access to finance, 3 respondents representing 7 percent showed that their dislike for bank loans is a major factor why they had not accessed any finance from banks, 3 respondents representing 7 percent said they have other factors and none representing 0 percent say they had no information on bank loans.

\subsection{Sources of SMEs Financing}

In total, 26 respondents representing 54 percent of the total respondents ranked their major source of funding to be personal savings followed by retained profits that was shown by 15 respondents representing 31 percent of the total respondents, third source of funding in rank was from family and friends loans and this accounted for only 5 respondents representing 11 percent, bank loans and sale of personal assets were ranked fourth and fifth respectively and these separately accounted for 1 respondent representing 2 percent of total respondents and none of the participating SMEs obtained finance for their business operations from Cooperatives, Micro finance institutions and inheritance from parents or relatives representing 0 percent.

In this case the majority of SMEs source of funds is through personal savings and very depend on bank loans and inheritance as their source of funding. A total of 32 respondents representing 67 percent generated their start up fund from personal savings, 7 respondents representing 15 percent of the total respondents generated their start- up funds from family and friends, 5 respondents representing 10 percent got their start-up funds from sale of personal assets, 2 respondents representing 4 percent got their start-up funds from bank loans and only 2 respondents representing 4 percent obtained their start- up funds from inheritance from parents/relatives.

In total, 25 respondents representing 53 percent of the respondent required bank loans to meet their working capital needs of the business, 15 respondents representing 32 percent required finance to help them expand their businesses, 8 respondents representing 15 percent required funding for bridging finance purposes and none of the respondents do not believe that banks are able to grant finance as start- up capital as reflected in the 0 percent respondents rate.

A total of 22 respondents representing 46 percent of the total respondents have an average relationship with their bankers, 15 respondents representing 32 percent said they have a good relationship, 7 respondents representing 14 percent said they had an excellent relationship and 4 respondents representing 8 percent of the total respondents said they have a poor relationship with their bankers. In total 35 respondents representing 73 percent obtained finance from cooperatives including village banks, 9 respondents representing 18 percent of the total respondents obtained funding from micro finance institutions respectively, 4 respondents representing 9 percent of the respondents obtained funding from non-governmental organizations.

A total of 37 out of the 48 respondents representing 77 percent strongly agreed that they have plans to expand their businesses, 15 out of the 48 respondents representing 31 percent supported the view, 11 out of the 48 respondents representing 23 percent disagreed with this view, 33 out of the 48 respondents representing 69 percent strongly agreed to the view, 32 out of the 48 respondents representing 67 percent strongly agreed to the view.

Table 3. Participating SMEs thoughts on business future and help they seek from banks

\begin{tabular}{|c|c|c|c|c|c|}
\hline Main SME statement or thoughts & $\begin{array}{l}\text { Strongly } \\
\text { agree }\end{array}$ & Agree & $\begin{array}{l}\text { Not } \\
\text { Sure }\end{array}$ & Disagree & Strongly disagree \\
\hline I would like to expand my business in future & 37 & 10 & 1 & 0 & 0 \\
\hline $\begin{array}{l}\text { Financial institutions do not explain the requirements for } \\
\text { obtaining loans }\end{array}$ & 12 & 15 & 7 & 11 & 3 \\
\hline $\begin{array}{l}\text { Financial institutions have stringent requirements and } \\
\text { conditions for obtaining loans }\end{array}$ & 33 & 8 & 1 & 5 & 1 \\
\hline $\begin{array}{l}\text { Financial institutions do not support SMEs with finance for } \\
\text { business operations }\end{array}$ & 32 & 6 & 3 & 6 & 1 \\
\hline $\begin{array}{l}\text { SMEs do not always use banks in their businesses- } \\
\text { channeling deposits }\end{array}$ & 7 & 11 & 5 & 19 & 6 \\
\hline $\begin{array}{l}\text { Financial institutions favour big \& established businesses } \\
\text { when granting lending }\end{array}$ & 39 & 6 & 1 & 1 & 1 \\
\hline Loan interest rates high and prohibitive & 36 & 9 & 1 & 0 & 2 \\
\hline SMEs are not aware of bank's lending criteria & 12 & 9 & 7 & 17 & 3 \\
\hline Loan maturity period are short and restrictive & 18 & 20 & 8 & 1 & 1 \\
\hline charges are too expensive & 26 & 12 & 3 & 6 & 1 \\
\hline
\end{tabular}


Every business has plans to grow just as witnessed by the 77 per cent in support of growth.

\section{Discussion}

Malawi as a country is an agricultural economy and exports primary agricultural products like tobacco, tea, coffee, sugar, cotton, groundnuts and legumes. There is a very small manufacturing base in the economy as such the country relies heavily on imports. The participating SMEs saw this opportunity and thrive in this niche. The 48 percent responses received were centered on the general business services and agricultural sectors. The general business services sector was the highest with 65 percent of the total responses as shown in the study results which were followed by the agricultural sector that accounted for only 11 percent, then the retail and wholesale trading at 8 percent and the transport sector at 8 percent. It was only the food and hospitality sector that had no responses.

The results also show the annual turnover for the 48 participating SMEs in the study where 21 of them recorded an annual turnover of over MK10 million representing 43 percent of the total respondents which is concentrated typically in the agricultural, general business services and transport sectors of the economy, 31 percent of them had an annual turnover ranging between MK500,000 and MK4 million and 17 percent had an annual turnover ranging between MK4 million and MK10 million with only 4 participant SMEs representing 9 percent had an average annual turnover of less than MK500, 000.

The study shows that the participating SMEs have the requisite business experience based on the length of period they have been in business hence considered mature enough to deal with commercial banks. The period of operation implies that majority of participating SMEs in this research were presumably experienced and productive. The study showed the types of participating SMEs for this study and where registered as sole proprietors, private companies, partnerships and family owned businesses. Some of these businesses employ people to help run their businesses. The table shows the highest qualifications of the people that are employed by these participating SMEs were 25 percent of employees hold a bachelor's degree, 25 percent have attained MSCE qualification, and 13 percent hold a JCE qualification while the majority representing 37 percent does not hold any formal educational qualification. The data shows that level of knowledge and experienced management is a problem in most SMEs. Apart from the owners, the participating SMEs do not have knowledgeable people within their ranks that can help nurture the businesses to greater heights. As a result convincing banks to lend to such entities pose a big problem. This information was necessary because the level of education can sometimes give an advantage in the success of business and

borrowing from lenders (Simanowitz \& Brody, 2004).

Every business desires to grow and encounter various challenges along the journey and SMEs are no exception. SMEs in Malawi face various challenges in their business operations and this was no different from the responses received from our sample respondents drawn from within the City of Blantyre. Each SME business who took part in the research was asked to rank in order of importance the major constraint they face in operating and expanding their businesses. According to the survey lack of finance represented 29 percent, competition represented 21 percent, high taxes represented 15 percent, corruption and bribes represented 11 percent and high interest rates represented 11 percent were ranked as the major constraints respectively. Despite the contribution from other mentioned constraints like crime and theft, lack of management skills and government incentives the participant SMEs still regards lack of finance as the major obstacle to the operations, growth and expansion of their businesses.

High interest rates are also said to be a major constraint to SME growth and expansion. As can be seen from Table 2 interest rates have been very high over the previous three years. Reserve Bank of Malawi has maintained the policy rate at an average of around 25 percent since 2013 as a result banks base lending rates have averaged around 38 percent. Banks respond to changes in policy rate in pricing and adjusting their base lending rate offered to customers. SMEs require financing to expand their operations and these kinds of rates are very prohibitive for them to access finance. The table further shows the huge gap between the base lending rates and savings rates by banks. The results of this study agree to the fact that participating SMEs consider high interest rates as a major constraint for them to access finance from banks.

A lot of factors are regularly mentioned as major contributors for SMEs failure to access finance from banks in Malawi. SMEA of Malawi emphasizes high borrowing costs, the requirements by lenders to ask for provision of collateral and strict criteria for acceptable collateral as some of the major challenges. Furthermore, banks are reluctant to use SMEA as guarantor for finance advanced to SMEs. SMEA further faults banks for inability to give out reasons for refusing granting loans to SMEs for professional reasons and the perception that they prefer dealing with already established large corporations. The study tested the possibility of participating SMEs ever 
accessing finance from banks and chance of being denied access to finance. The results show59 percent of the respondents attribute their failure to access finance was due to very high interest rates which makes it impossible to use bank loans in their businesses and 29 percent of the respondents stated that lack of collateral or security to pledge was the main reasons banks refused to grant them access to finance, inability by banks to accept mobile forms of collateral like cars also add to the problem.

The results from the research shows the frequencies of various factors hindering SMEs in securing finance for the growth and expansion of their businesses. Out of 48, 50 percent ranked inability to meet lending criteria as the major factor preventing them from accessing finance from banks, 38 percent ranked lack of collateral or security to pledge as factors affecting their ability to access finance, 6 percent stated that lack of financial information for the business was a major factor that prevented them from accessing finance, 6 percent of the respondents felt that bank altitude towards SMEs was the main reason why they could not access from the financial institutions and none of the participating SMEs believe that lack of experienced management team is a factor that prevented them from accessing finance. Furthermore, apart from inability to meet lending criteria, collateral and other factors, high interest rates is a factor that prevents SMEs from accessing credit.

From the study 57 percent of the respondents attribute their failure to access finance to very high interest rates which makes it impossible to use bank loans in their businesses as the high interest rates have a negative effect on their business margins, 29 percent of the respondents stated that lack of collateral or security to pledge as the main reasons banks refused to grant them access to finance. Inability by banks to accept mobile forms of collateral like cars compound the problem, 7 percent of the respondents show that their dislike for bank loans is a major factor why they have not accessed any finance from commercial banks as some SMEs do not believe in getting support from banks to expand their businesses and 7 percent of the respondents say that bank attitude is the major factor that prevents them from accessing finance as bank staff that are in charge of processing bank loans are not friendly and helpful to their businesses.

SMEs like any other business require finance for running business operations and finance for running SMEs come from a variety of sources. Finance can be obtained from both internal sources of finance which include retention of profits and reserves, selling assets and shareholders capital injection while external sources include family and friends especially for small businesses, banks, hire purchase agreements, trade credit, factoring, leasing, debentures and corporate bonds, venture capital and issuing shares to the public. As such, SMEs explore various sources of finance to enable them survive in business. Most participants SMEs have stated that internal sources of finance such as personal savings, sale of personal assets and retained profits are used mostly in their business financing. External sources of finance like bank loans, micro finance institutions, cooperatives and inheritance from relatives remain alternative sources of finance although not so popular.

The study aim to find the alternative sources of finance to SMEs and the study results show that 54 per cent of the total respondents ranked their major source of funding to be personal savings followed by retained profits that accounted for 31 per cent of the total respondents, third ranked source of funding was family and friends loans and this accounted for only 11 percent, bank loans and sale of personal assets were ranked fourth and fifth respectively and these separately accounted for 2 per cent of total respondents and none of the participants SMEs obtained finance for their business operations from Cooperatives, Micro finance institutions and inheritance from parents/relatives. The results suggest that sources of SME financing in Malawi are skewed towards internal sources of finance which has its own inherent limitations that stifles SMEs growth and expansion. The limitations include capacity and willingness to mobilise the resources timely. Furthermore, the results show that SMEs rarely use external sources like banks and cooperatives

Despite the country having nine commercial banks and almost each one of the major four listed banks have dedicated SME divisions, the study suggest that banks have very little or no interest at all in funding the SME sector. Banks get coy when approached for start-up business capital due to perceived huge risks in such ventures more especially if the applicants are SMEs. The little interest by banks to finance start -up capital is supported by data from the study results that shows the distribution of SMEs sources of finance for start- up businesses where it is evident that 67 percent and 15 percent of the total respondents respectively generated their start- up funds from personal savings and Family and friends respectively, 11 percent got their funds from sale of personal assets, 4 percent from bank loans and 3 percent obtained their start- up funds from inheritance from parents or relatives. These results make it very difficult for the participating SMEs to pursue growth and expansion of their businesses. Most of them remain static over several years and operate largely just for survival.

There are several reasons why participants SMEs need finance. The study shows that 53 percent of the respondent required bank loans to meet their working capital needs of the business, 32 percent required finance 
to help them expand their businesses while 15 percent required funding for bridging finance purposes. In effect, the funding needed was purely a timing difference issue between realisation of receivables and receipt of cash. SMEs do not believe that banks are able to grant finance as start- up capital as reflected in the 0 percent respondents' opinion from the research study. The relationship between banks and their customers is established and sustained when customers open and maintain bank accounts with their bankers. The study revealed that all participants representing 100 percent of the respondents SMEs held bank accounts with their respective bankers. However, the degree of the relationship can have an impact on the services and products that a customer enjoys. In view of this, the study wanted to gauge the relationship between the participants SMEs and their bankers as shown in study findings which shows that 46 percent of the total respondents have an average relationship with their bankers, 32 percent said they have a good relationship, 14 percent said they had an excellent relationship and 8 percent of the total respondents said they have a poor relationship with their bankers. It can be prudent to conclude that the overall unimpressive relationship that participant SMEs have with their bankers could be one of the factors why they do not access finance from banks.

SMEs require finance and would strive to obtain it from various sources and banks are traditionally sources of finance for businesses. The study sought to investigate which other sources do participants SMEs secure funding from other than banks. The study results show that 73 percent of the participants SMEs obtain finance from cooperatives including village banks, 18 percent of the total respondents obtain funding from micro finance institutions and 9 percent of the respondents obtained funding from Non-Governmental Organisations (NGOs).

The written questionnaire administered to the participant SMEs also sought to gather SMEs opinions on a range of issues they strongly believed in as tabulated above were discussion was centered SME views. Participants SMEs were asked to provide their views on whether they habour ambitions to expand their businesses in future, 37 out of the 48 respondents representing 77 percent strongly agreed that they have plans to expand their businesses which suggest that there is huge opportunity for collaboration with banks on funding for this requirement. Participants SMEs were asked to provide their views on assertions that banks do not explain the requirements for obtaining loans, 15 out of the 48 respondents representing 31 percent supported the view however, and 11 out of the 48 respondents representing 23 percent disagreed with this view. The small differences between these two views suggests that banks need to do more in engaging SMEs so that they are aware of the requirements for obtaining loans so that they can prepare thoroughly.

Participants SMEs were also asked to provide their views on assertions that banks have stringent requirements and conditions for obtaining loans, 33 out of the 48 respondents representing 69 percent strongly agreed to the view. The challenges of access to finance remain an issue today as depicted by these respondents. In continuing analysing the challenges participating SMEs face, the study also wanted to find out if SMEs support that banks do not support SMEs with finance for business operations, 32 out of the 48 respondents representing 67 percent strongly agreed to the view. Despite several commercial banks in Malawi having set up departments that specialise in SME businesses relationships, the participant SMEs strongly feel that they do not get adequate support from these banks. It can be concluded that most products and services banks offer are specifically negative to SMEs as they do not meet their expectations as shown.

\section{Conclusion}

Based on the responses from the participating SMEs, it became very clear that SMEs in Blantyre City face major challenges in accessing finance from banks. The main challenges exposed by the study include SMEs inability to meet bank's lending criteria, the lack of collateral or security to pledge and the inability by most SMEs to provide audited financial information for their businesses. The other impediment revealed is the high interest rates that have prevailed in Malawi from 2013 that have ranged from 35 percent to 45 percent. In total 59 percent of the respondents attribute their failure to access finance to very high interest rates which makes it impossible to use bank loans in their businesses. Furthermore, 29 percent of the respondents identified lack of collateral or security to pledge as the main reasons banks refused to grant them access to finance and inability by commercial banks to accept mobile forms of collateral like cars compounded the problem, as argued by SMEA.

\section{References}

Akeem, L. B. (2014). Banking Sector and the Development of SMEs in Osun State. Department of Accounting, Banking \& Finance Osun State University, Osogbo. Research Journal of Finance and Accounting, 5(4).

Banking Companies Ordinance. (1962). Part II-Business of Banking Business. Retrieved from http://www.google.com

Brealey, R. A., Myers, S. C., Marcus, A. J., Maynes, E. M., \& Mitra, D. (2012). Fundamentals of Corporate 
Finance (5th ed.). McGraw-Hill, Ryerson, Canada.

Cofie, A. A. (2012). Challenges of financing Small and Medium Scale Enterprises in Ashanti Region, Ghana. A case study of Stanbic Bank (GH) Ltd.

Coleman, S. (2000). Access to Capital: A Comparison of Men and Women Owned Small Businesses. Journal of Small Business Management, 38(3), 37-52.

Credit Reference Bureau Act. (2015). Laws of Malawi. Retrieved from http://www.google.com

De la Torre, A., Soledad, Pería, M. \& Schmukler, S. L. (2010). Bank Involvement with SMEs: Beyond Relationship Lending. Journal of Banking \& Finance, 34(9), 2280-2293.

Fatoki, O. O., \& Smith, A. V. A. (2011). Constraints to credit access by new SMEs in South Africa: A supply-side analysis. African Journal of Business Management, 5(4), 1413-1425.

Financial Institutions Supervision Annual Report. (2014). Retrieved from http://www.google.com

FinScope MSME Survey Malawi. (2012). Retrieved from http://www.google.com

Firth, M., Lin, C., Liu, P., \& Wong, S. M. L. (2009). Inside the Black Box: Bank Credit Allocation in China's Private Sector. Journal of Banking \& Finance, 33(6), 1144-1155.

Frimpong, S. K., \& Antwi, D. A. (2014). Sources of financing Small Scale Enterprises in Akwapim North Municipal Assembly, Ghana.

Grover, A., \& Suominen, K. (2014). 2014 Summary - State of SME Finance in the United State, White paper, Trade up.

Kalaile, F. (2016). Business Review; Volume 23, Number 227. The Nation Newspaper.

Kambewa, P., \& Tekere, M. (2007). The Impact of economic partnership agreements on micro, small and medium enterprises in Malawi: the example of tobacco, sugarcane and garment producers. Integrated framework policy analysis, Working Paper Series Number 5.

Kazooba, T. C. (2006). Causes of small business failure in Uganda: a case study from Bushenyi and Mbarara Towns. African Studies Quarterly, 8(4).

Le, N. T. B., \& Nguyen, T. V. (2009). The Impact of Networking on Bank Financing: The Case of Small and Medium-Sized Enterprises in Vietnam. Entrepreneurship Theory and Practice, 33(4), 867-887.

Malawi Banking Act. (2009). Retrieved from http://www.google.com

Malawi Government. (2002). Malawi Poverty Reduction Strategy Paper. Lilongwe: Government of Malawi.

Malawi Government. (2013-2018). National Export Strategy, Lilongwe: Government of Malawi.

Malawi Government's Ministry of Commerce and Industry policy statement on Small and Medium Enterprises. (2002).

Mayowa, R. (2014). Commercial banks credit and SMEs development in Nigeria: an empirical review. International Journal of Research (IJR), 1(8). Commercial Banks' Credit and SMEs Development. Kogi State University.

Moore, C. W., Petty, W. J., Palich, L. E., \&Longenecker, J. G. (2008). Managing Small Business: An Entrepreneurship Emphasis (14th ed.). South-Western Cengage Learning, United States of America.

Mukamuganga, C. (2011). The Role of SMEs in Rwanda from 1995 to 2010. National University of Rwanda.

Mullen, M. (2012). Best Practice Guideline SME Finance, Corporate Finance Faculty, Department for Business Innovation and Skills. BIS, (58).

Myers, C. S. (1984). The Capital Structure Puzzle, Journal of Finance, 39(1), 575-592.

Nofsinger, J. R., W. Wang (2011). 'Determinants of Start-up Firm External Financing Worldwide. Journal of Banking \& Finance, 35(9), 2282-2294.

Nuttal, C. J. (2002). Business Studies. London: Cambridge University Press.

Nyandwi, V. (2013). Contribution of small and medium enterprise to the economic development of Rwanda. UniversiteNationale du Rwanda.

Olowe F. T. (2013). Empirical Study of the Impact of Microfinance Bank on Small and Medium Growth in Nigeria. 
Peterhoff, D., Romeo, J., \& Calvey, P., (2014). Towards better capital markets solutions for SME financing. Oliver Wymann.

Planningand Research Department, SME Development Institute. (2015). Lilongwe, Malawi.

Quainoo, T. K. (2011). Examining the impact of loans on SMEs in Ghana. The Institute of Distance Learning, Kwame Nkrumah University.

Quaye, I., \& Sarbah, A. (2014). Assessing alternative sources of finance for Small and Medium Scale enterprises in Ghana.A case of savings and Loan companies in the Greater Accra region. Retrieved from http:/www.ijoart.org/docs/ASSESSING-ALTERNATIVE-SOURCES-OFFINANCING-FOR-SMALL-ME DIUM-SCALE.pdf

Scarborough, N. M. (2013). Essentials of Entrepreneurship and Small Business Management (6th ed.). Pearson Education Limited, England.

Seker, M., \& Correa, P. G. (2010). Obstacles to growth for small and medium enterprises in Turkey (WPS 5323). Retrieved from http://econ.worldbank.org

Simanowitz, A., \& Brody, A. (2004). Realising the potential of microfinance, id21 insights, December, Issue 51.

Stokes, D., \& Wilson, N. (2010). Small Business Management and Entrepreneurship (6th ed.). Cengage Learning EMEA.

Sveinung, F., \& Grünfeld, L. E, (2010). SME and Growth in Sub-Saharan Africa.

The Malawi Companies Act. (2013). Retrieved from http://google.com

The Reserve Bank of Malawi Financial Institutions Supervision Annual Report. (2015).

Torre, A., Peria, M., \& Schmukle, S. (2010). Bank involvement with SMEs: Beyond relationship lending. Journal of Banking \& Finance, 34, 2280-2293.

World Bank. (2009). Enterprises Survey.

Wymenga, P., Spanikova, V., Barker, A., Konings, J., \& Canton, E. (2012). EU SMEs in 2012: At the Crossroads. Annual Report on Small and Medium-sized Enterprises in the EU, 2011/12. Report for the European Commission.

\section{Copyrights}

Copyright for this article is retained by the author(s), with first publication rights granted to the journal.

This is an open-access article distributed under the terms and conditions of the Creative Commons Attribution license (http://creativecommons.org/licenses/by/4.0/). 